\title{
Hydrologic effects of land and water management in North America and Asia: 1700-1992
}

\author{
I. Haddeland ${ }^{1,2}$, T. Skaugen ${ }^{1,2}$, and D. P. Lettenmaier ${ }^{3}$ \\ ${ }^{1}$ Department of Geosciences, University of Oslo, Oslo, Norway \\ ${ }^{2}$ Norwegian Water Resources and Energy Directorate, Oslo, Norway \\ ${ }^{3}$ Department of Civil and Environmental Engineering, University of Washington, Seattle, USA
}

Received: 28 July 2006 - Published in Hydrol. Earth Syst. Sci. Discuss.: 19 September 2006

Revised: 17 January 2007 - Accepted: 23 March 2007 - Published: 29 March 2007

\begin{abstract}
The hydrologic effects of land use changes, dams, and irrigation in North America and Asia over the past 300 years are studied using a macroscale hydrologic model. The simulation results indicate that the expansion of croplands over the last three centuries has resulted in 2.5 and 6 percent increases in annual runoff volumes for North America and Asia, respectively, and that these increases in runoff to some extent have been compensated by increased evapotranspiration caused by irrigation practices. Averaged over the year and the continental scale, the accumulated anthropogenic impacts on surface water fluxes are hence relatively minor. However, for some regions within the continents human activities have altered hydrologic regimes profoundly. Reservoir operations and irrigation practices in the western part of USA and Mexico have resulted in a 25 percent decrease in runoff in June, and a 9 percent decrease in annual runoff volumes reaching the Pacific Ocean. In the area in South East Asia draining to the Pacific Ocean, land use changes have caused an increase in runoff volumes throughout the year, and the average annual increase in runoff is 12 percent.
\end{abstract}

\section{Introduction}

In ancient times some dams and aqueducts were built for irrigation and water supply, but the impact of human activities on runoff and evapotranspiration was minor. More recently, water management structures have become increasingly essential to provide water supply, as well as electric power, navigation, flood control, and other amenities for a growing population. Dams, built for water storage, and water withdrawals, e.g. for irrigation purposes, directly change the dynamics of the water cycle, and humanity has extensively altered river systems through diversions and impoundments.

Correspondence to: I. Haddeland

(ingjerd@geo.uio.no)
In addition, surface water fluxes are indirectly influenced by land use changes, e.g. deforestation. Anthropogenic impacts have altered the natural water balance profoundly, at least at the local scale. Several rivers, like the Colorado, the Indus, and the Huang He Rivers are used so extensively that during parts of the year little or no water reaches the sea (Falkenmark and Lannerstad, 2005), and the Aral and Caspian Seas have been reduced in extent because of water extractions for agriculture (Vörösmarty and Sahagian, 2000).

According to Vitousek et al. (1997), humans have transformed more than one-third of the Earth's land surface, mainly for the purpose of producing goods and services. The expansion of croplands has resulted in a 20 percent reduction in forest cover since 1700 (Ramankutty and Foley, 1999). Both field experiments and modeling studies have shown that reduced forest cover in general increases runoff and reduces evapotranspiration (Sahin and Hall, 1996; Matheussen et al. 2000; Costa et al. 2003; Twine et al. 2004). According to FAOSTAT (available at http://faostat.fao.org/), a database maintained by the Food and Agriculture Organization of the United Nations (FAO), $2.8 \times 10^{6} \mathrm{~km}^{2}$ land is currently (2003) equipped for irrigation globally; about twice the size of the area equipped for irrigation in 1961. Several modeling projects have studied the effects of irrigation on water balance components globally, e.g. Döll and Siebert (2002). Land use changes affect albedo and evapotranspiration, and the effects on climate have received much attention, both on the local and the global scale, see Gibbard et al. (2005), Lobell et al. (2006), and references therein, but continental-scale hydrologic analyses of the effect of land use changes are rare. Gordon et al. (2005) quantified changes in evapotranspiration due to deforestation and irrigation at the global scale, and concluded that the effects of irrigation on evapotranspiration are as important as the effects of deforestation.

In addition to land cover changes, humans have altered natural water cycles by building dams, and the World

Published by Copernicus GmbH on behalf of the European Geosciences Union. 
Register of Large Dams (ICOLD, 2003) includes more than 33000 dams (defined as being $15 \mathrm{~m}$ or higher). The volume of water that can be stored in reservoirs formed by large dams is about $6600 \mathrm{~km}^{3}$, or about 15 percent of annual continental runoff (Postel et al., 1996). The effects of dams on the water balance can be profound, see e.g. Vörösmarty et al. (1997), Nilsson et al. (2005), and Hanasaki et al. (2006). Haddeland et al. (2006b) studied the effects of dams and irrigation given current conditions, and found locally significant changes in the surface water fluxes. The purpose of this paper is to study the hydrologic effects of dams in comparison with cropland expansion, and irrigation practices over the past 300 years for North America and Asia. 80 percent of the area equipped for irrigation globally (Siebert et al., 2005a), and more than 70 percent of the world's large dams (ICOLD, 2003) are located within these two continents.

\section{Approach}

\subsection{Hydrology model}

The Variable Infiltration Capacity (VIC) macroscale hydrology model (Liang et al., 1994) is a grid-based model that usually is implemented at spatial scales from one-eighth to two degrees latitude by longitude, and at hourly to daily temporal resolution. Each grid cell is partitioned into multiple vegetation types, and the soil column is divided into multiple (typically three) soil layers. Evapotranspiration is calculated using the Penman-Monteith equation. The most influential vegetation parameter in the VIC evapotranspiration scheme is leaf area index (LAI). The saturation excess mechanism, which produces surface runoff, is parameterized through the Xinanjiang variable infiltration curve (Zhao et al., 1980). Release of baseflow from the lowest soil layer is controlled through the non-linear Arno recession curve (Todini, 1996). Surface runoff and baseflow, which combined is termed runoff in the remainder of this paper, is routed for each cell to the basin outlet through a channel network as described by Lohmann et al. (1998). In this paper, the term river runoff is used when referring to water in the channel network.

The VIC model has been extensively evaluated using river basin and point flux data both regionally (Bowling et al., 2003; Christensen et al., 2004), continentally (Maurer et al., 2002), and globally (Nijssen et al., 2001). In all of these applications, the model has been shown to reproduce the water cycle well when the forcings are known.

An irrigation scheme and a reservoir model were recently added to the VIC model (Haddeland et al., 2006a, b). The irrigation scheme is based on the model's simulated soil moisture, and extracts surface water locally, or, in periods of water scarcity, from reservoirs or any other prescribed point in the river basin. The VIC model, like most land surface schemes, does not represent groundwater in a way suitable for model- ing groundwater withdrawals, which therefore are not taken into account in the model. Reservoir operations are based on simulated reservoir inflow, reservoir evaporation, storage capacity and downstream water or power demands, using an optimization scheme based on the SCEM-UA algorithm (Vrugt et al., 2003) to calculate optimal releases. Irrigation demands are calculated based on simulated irrigation water requirements downstream of the dam. For flood protection and hydropower dams, the optimization scheme is used to minimize flood damages and to maximize hydropower production, respectively. When a dam has multiple purposes, irrigation demands are given priority, followed by flood control. Any excess water is used to maximize hydropower production, if applicable. The model can be run assuming water availability is not a limiting factor, in which case it calculates irrigation water requirements (which are defined as the water required in addition to water from precipitation (soil moisture) for optimal plant growth during the growing season, i.e. the difference between potential evapotranspiration and actual evapotranspiration). When the modeling scheme takes into account how much water is actually available (locally or in upstream reservoir(s) built for irrigation purposes), consumptive irrigation water use is calculated. Validation runs have shown that the model simulates irrigation water requirements that are close to the reported ones, and the model is able to capture the main hydrologic effects of reservoir operations and irrigation water withdrawals (Haddeland et al., 2006a, b). The reservoir model and irrigation scheme are described in more detail in Haddeland et al. (2006a, b).

\subsection{Study areas and input data}

The regions studied include most of Asia (including parts of Eastern Europe), and North America (Mexico, USA, and Canada), see Fig. 1. These regions include some of the most heavily irrigated areas in the world, and account for about 80 percent of the areas equipped for irrigation globally (Siebert et al., 2005a). In addition, about 70 percent of the dams registered in the World Register of Dams (ICOLD, 2003) are located in North America and Asia.

Daily atmospheric forcing data were obtained from Adam et al. (2006) and Maurer et al. (2002). The meteorological data were gridded time series of precipitation, temperature, and wind speed at 0.5 degrees latitude-longitude spatial resolution. Precipitation and temperature were based on meteorological station observations, and wind speed was obtained from (daily) NCEP/NCAR reanalysis data (Kalnay et al., 1996), see Adam et al. (2006) and Maurer et al. (2002) for details.

Elevation data were calculated based on GTOPO30, a 30 arc-second global digital elevation model (available at http: //edc.usgs.gov/products/elevation/gtopo30/gtopo30.html), and vegetation types were based on the University of Maryland global classifications at $1 \mathrm{~km}$ resolution described by Hansen et al. (2000). Within the United States, soil 

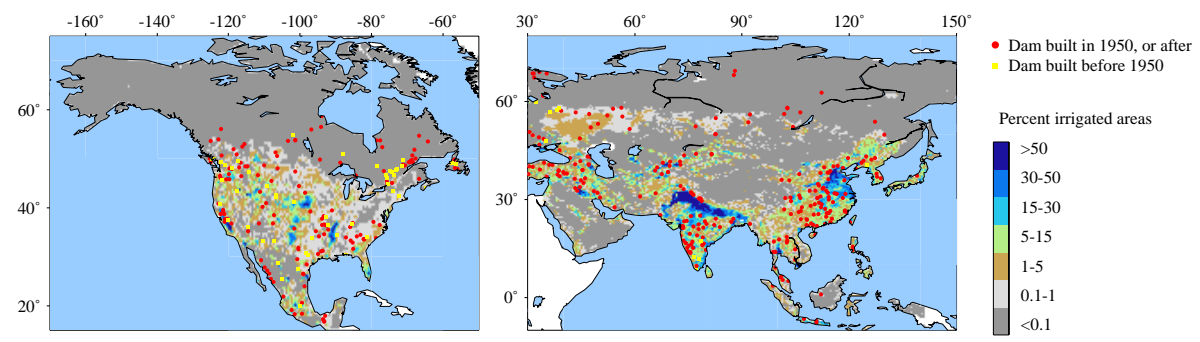

Fig. 1. The study areas, including the location of the dams taken into account in this study, and the percent irrigated area within each 0.5 degree grid cell.
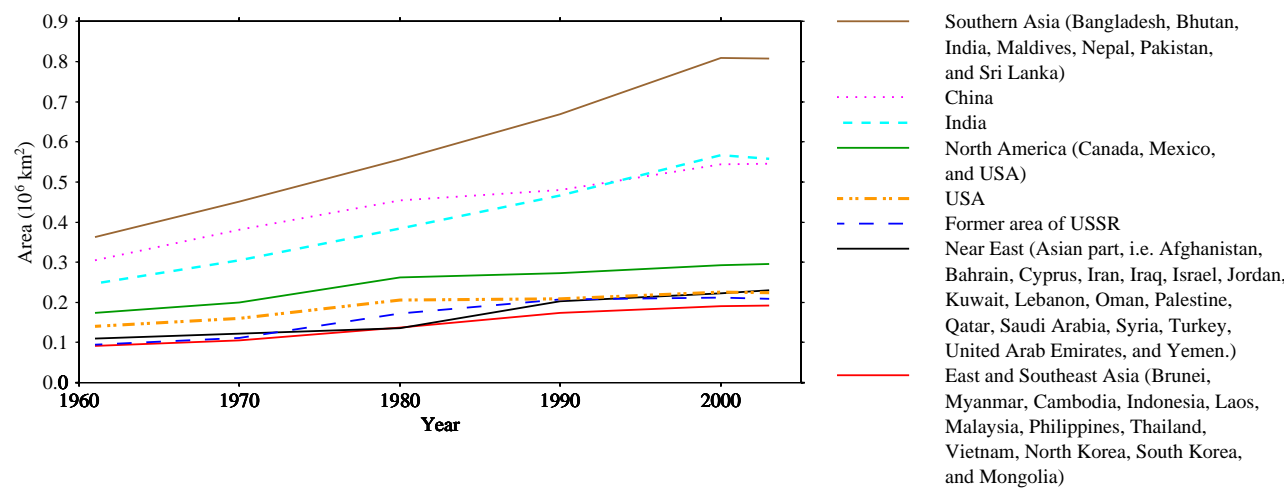

Fig. 2. Irrigated areas within countries and regions, 1961-2003. Data are obtained from FAO (http://faostat.fao.org).

types were based on the 1-km-resolution dataset produced by the Pennsylvania State University (Miller and White, 1998), while soil types for the remaining areas were based on FAO's 5-min dataset (FAO, 1998), see more detailed information in Maurer et al. (2002) and Nijssen et al. (2001). Potential vegetation (the vegetation that would have existed absent anthropogenic effects and absent certain disturbances such as fires and pests) and data on historical cropland cover were obtained from the SAGE database (available at http://www.sage.wisc.edu). These datasets are described in Ramankutty and Foley (1999), and include potential vegetation at $5 \mathrm{~min}$ resolution, and cropland data (fraction within cell) at 0.5 degrees resolution for the period 1700-1992. The current vegetation images (Ramankutty and Foley, 1999 and Hansen et al., 2000) differ somewhat, but the main vegetation patterns are similar at large scales. The important issue for this study, though, is what kind of vegetation was present in cropland areas before they were converted to agricultural use. To this end, we assumed that the natural vegetation of Ramankutty and Foley (1999) represents the vegetation that would have occurred in the areas now covered by crops.

Data on irrigated areas were obtained from Siebert et al. (2005a), see Fig. 1. Information on areas equipped for irrigation within each country from 1961 up to now was obtained from FAOSTAT (available at http://faostat.fao.org/), see Fig. 2. Information about dam heights, operating purposes, and storage capacities were obtained from the World Register of Dams (ICOLD, 2003), and georeferencing of the dams was from Vörösmarty et al. $(1997,2003)$. The dam dataset used in this study globally includes 668 dams, of which 183 (total storage capacity: $1192 \mathrm{~km}^{3}$ ) are located in the North American region, and 257 (total storage capacity: $1782 \mathrm{~km}^{3}$ ) in the Asian region. Figure 3 shows the number of dams built within each 10-year interval since 1900, and the accumulated storage capacity of the dams.

\subsection{Model simulations}

Model simulations were performed for current $(\sim 1992)$ and historical (1700, 1900, and 1950) conditions (Sect. 3 describes how the input data for historical conditions were constructed). For 1950 and 1992, simulations were performed both with and without the irrigation scheme and reservoir model implemented, which allows study of land use changes alone. For the simulations with the reservoir model included, only dams that were built in, or before, the simulation year were taken into account. All simulations were performed at daily time steps, using meteorological data for a 20 -year period (1980-1999). Hence, the results should be interpreted as indicating the predicted hydrologic response where the indicated land cover and water management scenarios occur with 

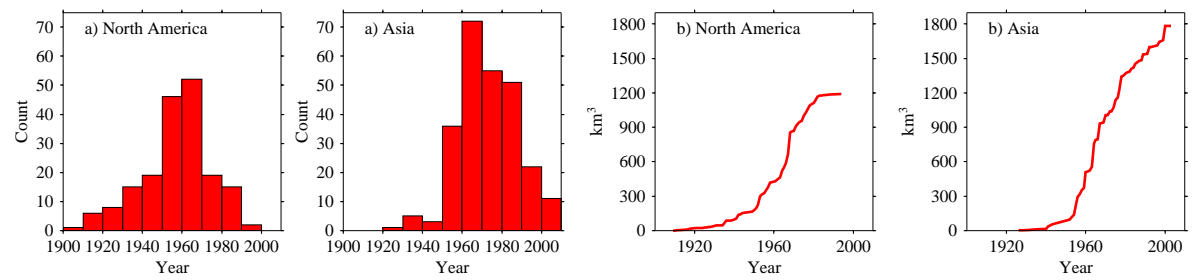

Fig. 3. (a) Histogram of when the dams were built, and (b) Accumulated storage volume. Only dams included in this study are taken into account. Data are obtained from the ICOLD database (ICOLD, 2003).
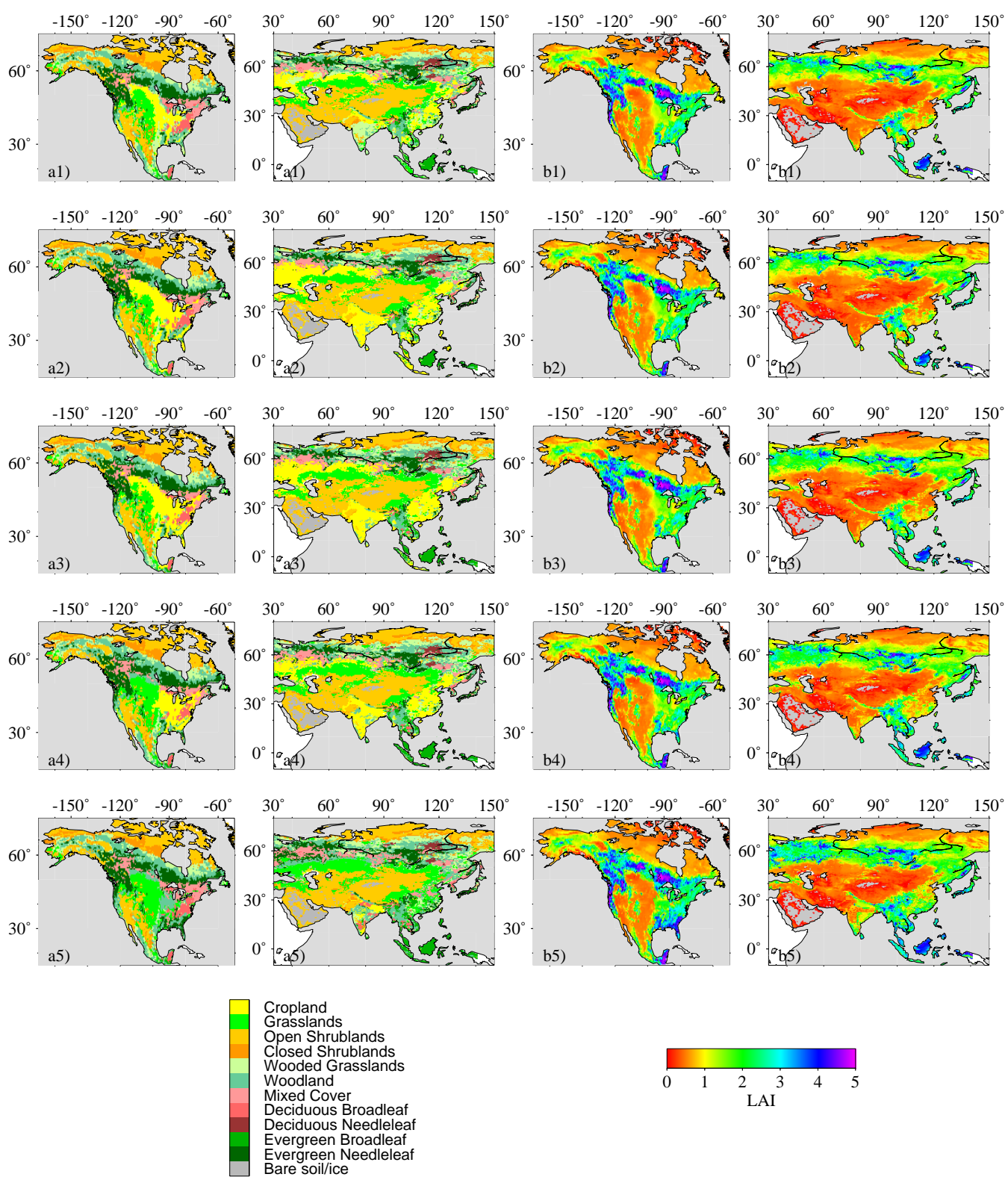

Fig. 4. (a) Dominant vegetation type, and (b) mean annual leaf area index value within grid cell.1: 1992 (original), 2: 1992 (modified), 3 : 1950, 4: 1900, 5: 1700 . 

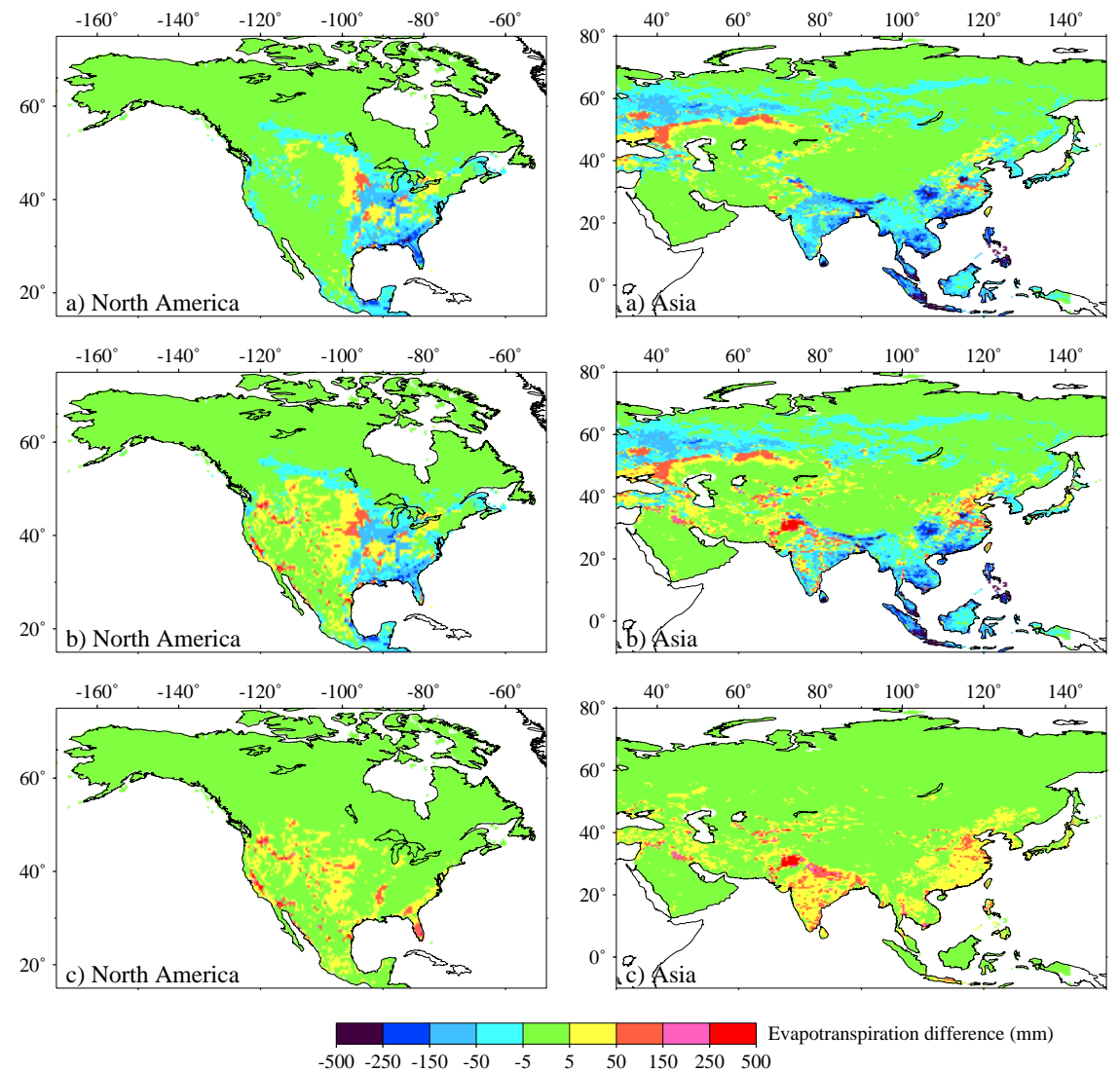

Evapotranspiration difference $(\mathrm{mm})$

Fig. 5. Spatial effects on evapotranspiration. (a) The difference between current (1992) simulation results, without irrigation and reservoirs, compared to historical (1700) simulation results. (b) The difference between current (1992) simulation results, with irrigation and reservoirs, compared to historical (1700) simulation results. (c) The difference between current (1992) simulation results, with irrigation and reservoirs, and current (1992) simulation results, without irrigation and reservoirs. Notice the uneven legend intervals.

the current climate (stated otherwise, the effects of possible climate change over the past 300 years is not considered).

\section{Historical land cover conditions}

\subsection{Historical vegetation}

In order to study the changes in runoff and evapotranspiration associated with land-cover changes, several vegetation images were constructed, representing the current $(\sim 1992)$ and historical $(1700,1900$, and 1950) conditions. The vegetation images were inferred from the current vegetation image, and Ramankutty and Foley's (1999) potential vegetation and cropland datasets.

In Haddeland et al. (2006b), vegetation types were obtained from Hansen et al. (2000) combined with LAI values based on Myneni et al. (1997), as described in Nijssen et al. (2001). The cropland dataset (Ramankutty and Foley, 1999) includes larger areas of cropland in 1992 than Hansen et al.'s (2000) vegetation image. In order to make the comparisons between the current and historical simulations more consistent, the current vegetation image was slightly modified. That is, cropland areas in the current vegetation image were matched to the cropland areas of Ramankutty and Foley (1999). The modified current vegetation image thus has more cropland areas than the original vegetation image; mainly on the expense of wooded grasslands and grasslands. If Ramankutty and Foley's (1999) cropland dataset had cropland in a cell where the current vegetation image contains no cropland, LAI values for cropland were taken from adjacent cells and averaged. The original and modified vegetation images are shown in Fig. 4.

Ramankutty and Foley's (1999) potential vegetation image is available at $5 \mathrm{~min}$ (1/12 degree) spatial resolution. These data were aggregated to 0.5 degrees spatial resolution, where each resulting grid cell includes information on fraction of each vegetation type within the area covered by the 0.5 degree grid cell. Ramankutty and Foley (1999) 
Table 1. Vegetation cover in study area $\left(10^{6} \mathrm{~km}^{2}\right), 1700-1992$.

\begin{tabular}{lcccc}
\hline & 1700 & 1900 & 1950 & 1992 \\
\hline $\begin{array}{l}\text { Forest (includes evergreen and } \\
\text { deciduous trees, and mixed cover) }\end{array}$ & 16.1 & 13.1 & 12.1 & 11.2 \\
Woodland (includes wooded grassland) & 17.9 & 16.5 & 15.8 & 15.8 \\
Shrubland & 15.5 & 15.2 & 14.9 & 14.6 \\
Grassland & 10.1 & 8.4 & 7.5 & 7.1 \\
Bare soil & 2.8 & 2.8 & 2.8 & 2.8 \\
Cropland (irrigated) & $2.4(0)$ & $8.4(0)$ & $11.2(0.9)$ & $12.6(2.1)$ \\
Total & 69.4 & 69.4 & 69.4 & 69.4 \\
\hline
\end{tabular}

Table 2. Simulated mean annual evapotranspiration and runoff $\left(\mathrm{km}^{3} \mathrm{year}^{-1}\right)$.

\begin{tabular}{lcccc}
\hline & North America & \multicolumn{2}{c}{ Asia } \\
& ET & Q & ET & Q \\
\hline 1700, no irrigation, no reservoirs & 9650 & 6005 & 23684 & 14988 \\
1900, no irrigation, no reservoirs & 9482 & 6173 & 23127 & 15554 \\
1950, no irrigation, no reservoirs & 9456 & 6199 & 22925 & 15747 \\
1950, irrigation and reservoirs & 9524 & 6132 & 23085 & 15589 \\
1992, no irrigation, no reservoirs & 9495 & 6158 & 22761 & 15913 \\
1992, irrigation and reservoirs & 9610 & 6047 & 23165 & 15517 \\
1992, irrigation water assumed freely available & 9716 & 5931 & 23475 & 15198 \\
\hline
\end{tabular}

classifies vegetation somewhat differently than does Hansen et al. (2000), and the potential vegetation images was therefore matched to Hansen et al.'s (2000) classification scheme. LAI values for the potential vegetation were thereafter inferred from the current vegetation image.

Historical (1700-1950) vegetation images were constructed by adjusting cropland area in the modified current vegetation image according to Ramankutty and Foley's (1999) information on changes in cropland fraction within each 0.5 degree cell between 1992 and the year of interest. Cropland areas were substituted with potential vegetation, or, in the case of a higher historical than current percentage cropland within the cell, current vegetation types were replaced by cropland. Table 1 gives the amount of different vegetation types in the current and historical vegetation images, see also Fig. 4.

\subsection{Irrigated areas}

The global map of irrigated areas from Siebert et al. (2005a) was used as the baseline image of irrigated areas around the year 2000. FAOSTAT (available at http://faostat.fao.org/ includes information on irrigated areas in each country for each year since 1961, see Fig. 2. For countries that were a former part of USSR, USSR information for the period 1961-1990 were used to estimate the change in irrigated areas within each country. For all countries, estimates for 1950 were obtained by extrapolating the data for the period 1961-
1970 (assuming a linear trend). No irrigation was included in the simulations for 1900 and before. The location of irrigated areas were somewhat adjusted, to make sure fraction irrigated area within each cell is less than, or equal to, cropland area given by Ramankutty and Foley (1999). However, changes in irrigated area within each country for each year were constrained to the FAOSTAT values.

\section{Results and discussion}

\subsection{Continental results}

Figure 5 shows simulated mean annual evapotranspiration values within each 0.5 degree grid cell for current conditions, both with and without the reservoir and irrigation scheme implemented, compared to the historical (1700) values. Areas where current evapotranspiration values are different from the historical values to some extent reflect the vegetation changes shown in Fig. 4. Conversion of land area from forest or woodland to cropland leads to decreased evapotranspiration and increased runoff, e.g. in Florida, in Russia north of $\sim 50 \mathrm{~N}$, and in Eastern and South East Asia, see Fig. 5a). In these areas current LAI values are lower than historical LAI values (see Fig. 4), which in general leads to increased runoff (Sahin and Hall, 1996). In Russia south of $\sim 50 \mathrm{~N}$, which originally was dominated by grassland but is currently dominated by cropland, the opposite trend is apparent, and current evapotranspiration values are higher than 

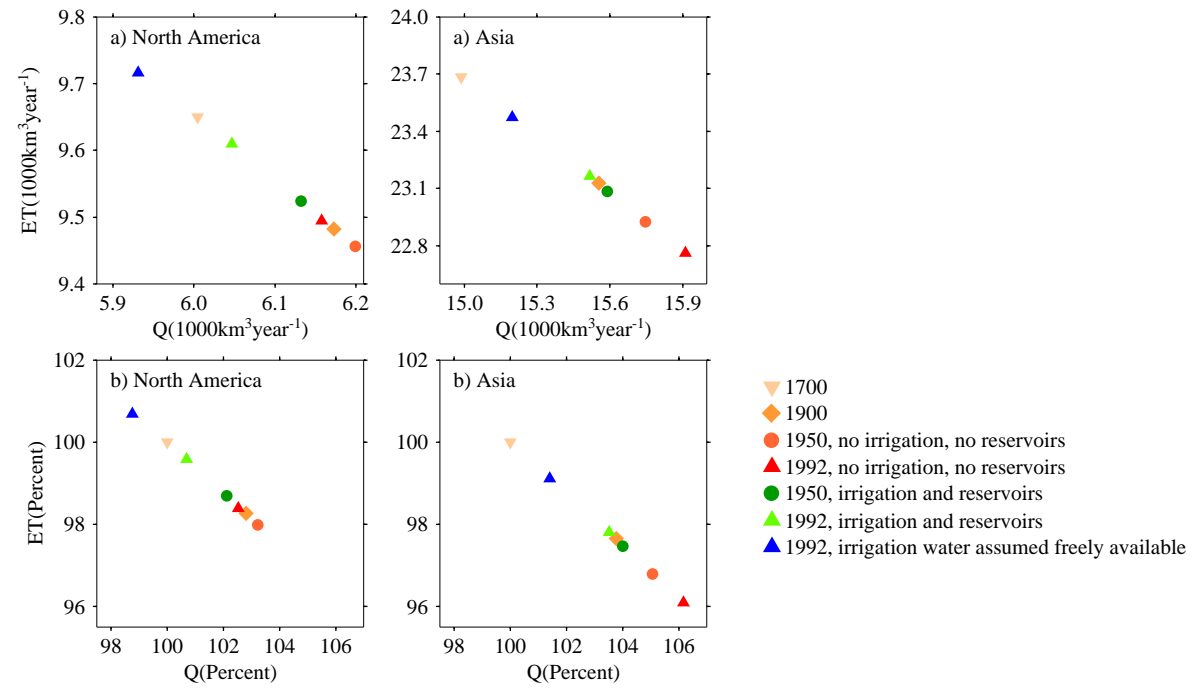

Fig. 6. Water balance components (ET: Evapotranspiration, Q: Runoff) for all simulations. (a) Mean annual values, and (b) Relative amount compared to the simulations for the year 1700. The numbers do not include reservoir evaporation or changes in reservoir storage.

historical evapotranspiration values (grassland in general has lower LAI values than cropland). When looking at Fig. 5c), it is apparent that the areas that are relatively most affected by irrigation practices are located in the USA, Pakistan, India, and China.

In the Mississippi River basin, simulated evapotranspiration has decreased in the eastern part, which has been converted from forested areas to cropland, and increased in the western part, which has experienced conversion from grassland to cropland, see Fig. 5. Twine et al. (2004) studied the effects of land cover changes on the water balance of the Mississippi River basin, and found 10 percent decreases in mean annual evapotranspiration values over areas of former forest and savanna, and 15 percent increase in mean annual evapotranspiration values over areas of former grasslands. In general, these trends are similar to the ones seen in Fig. 5a), which compares the historical situation to the current situation, without taking reservoirs and irrigation practices into account.

Total simulated current runoff values for the North American and Asian regions are 6050 and $15500 \mathrm{~km}^{3}$ year $^{-1}$, respectively, while the corresponding numbers on evapotranspiration are 9600 and $23200 \mathrm{~km}^{3}$ year ${ }^{-1}$. Water balance numbers for all simulations are presented in Fig. 6, and in Table 2. The simulations are performed using the same 20year period (1980-1999) of meteorological data, i.e. the simulation results are not affected by possible climate changes. Figure 6 indicates that land use changes in the Asian region on average have affected runoff and evapotranspiration more than in the North American region. The largest simulated increases in runoff values are about 3 percent for North America, and about 6 percent for Asia. In Asia, the highest simulated total runoff is for current conditions without taking reservoirs and irrigation practices into account, and land use changes have caused a gradual increase in runoff over the past 300 years. Simulated irrigation water requirements in Asia are about 70 percent of the simulated decrease in evapotranspiration caused by land use changes, whereas simulated water use is about half this number. In North America, cropland mainly replaced areas of forest and woodland between 1700 and 1900, resulting in an increase in runoff values. Between 1900 and 1950, the agricultural expansion in the Midwestern USA took place on the expense of grassland areas (see also Fig. 4), and runoff consequently decreased somewhat in these areas compared to the 1900 values. Elsewhere, e.g. in Florida, cropland areas replaced forested areas during the same 50-year period, and averaged over North America runoff increased between 1900 and 1950. After 1950, cropland expansion results in decreased runoff values. Simulated irrigation water requirements in North America are higher than the simulated increases in runoff values caused by land use changes. However, simulated current water uses are similar to the simulated increases in runoff values caused by land use changes, and simulated current runoff and evapotranspiration are hence practically the same as the 1700 values.

Gordon et al. (2005) found that deforestation has decreased global vapor flows by $3000 \mathrm{~km}^{3} \mathrm{year}^{-1}$, and that global irrigation water requirements are $2600 \mathrm{~km}^{3}$ year $^{-1}$, but they do not report results by continent. It is, however, evident that the Gordon et al. (2005) numbers for North America and Asia are higher than the simulations presented here. The irrigation water requirements presented in Fig. 6 are in reasonable agreement with the irrigation water requirements reported in FAO's database AQUASTAT (http: //www.fao.org/ag/agl/aglw/aquastat/main), see also Haddeland et al. (2006b). The Gordon et al. (2005) study reports 

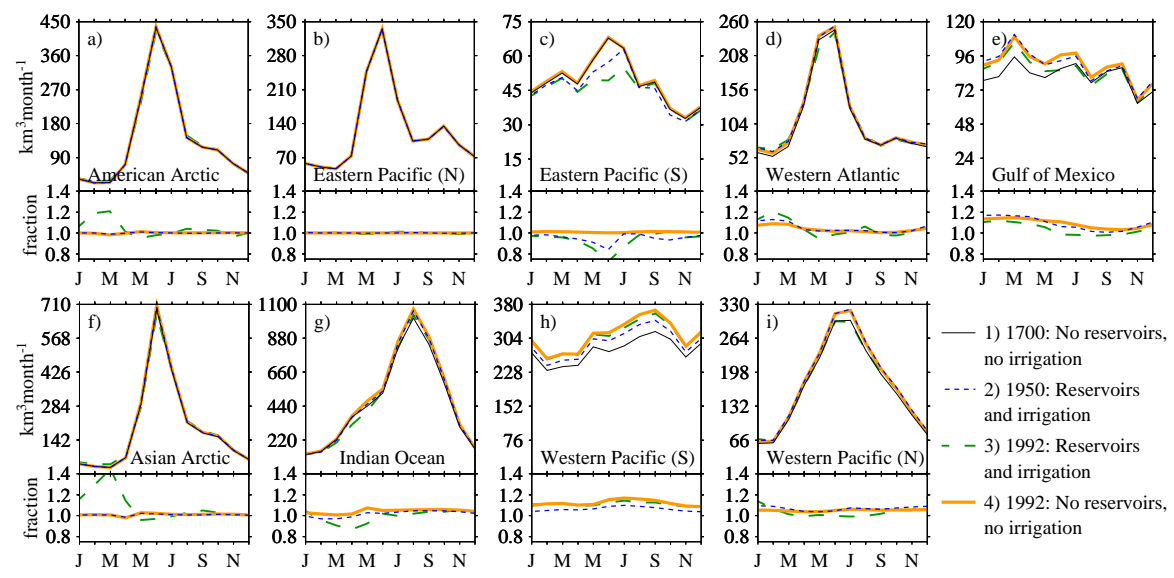

Fig. 7. Effects on freshwater fluxes reaching the oceans. (a) represents rivers draining northwards to the Arctic Ocean in the North American region (including Hudson Bay), (b) and (c) represent rivers draining North America to the Pacific Ocean north and south of $49 \mathrm{~N}$, respectively. (d) represents rivers draining North America to the Atlantic Ocean, (e) represents rivers draining to the Gulf of Mexico, (f) represents rivers draining northwards to the Arctic Ocean in the Asian region, (g) represents rivers draining Asia to the Indian Ocean, and (h) and (i) represent rivers draining Asia to the Pacific Ocean north and south of the Tropic of Cancer, respectively. The lower panels show the results of simulations 2, 3 and 4 divided by simulation 1 .

substantial decreases in evapotranspiration caused by land use changes in Eastern China, decreases that are not as significant in this study. Differences in the vegetation images and models are most likely the main factors that lead to the discrepancies. The LAI values used for 1700 conditions (see Fig. 4b5), and method of calculating evapotranspiration in this study, might result in less evapotranspiration than the method used by Gordon et al. (2005). Gordon et al. compared current land cover conditions to potential vegetation, while the historical (1700) vegetation image used in this study is somewhat affected by humans. However, both studies use the Ramankutty and Foley (1999) dataset, which indicates that only 3 percent of the global land area was cropland in 1700 (see also Table 1 and Fig. 4).

\subsection{River runoff to the ocean.}

Simulated mean monthly runoff for various continental areas to the ocean is shown in Fig. 7, which in addition shows runoff relationships between the simulation results. At the monthly level, the largest simulated differences between current ( $\sim 1992$, reservoirs and irrigation included) and historical (1700) conditions are observed in the early summer in the North American area draining to the Eastern Pacific south of $49 \mathrm{~N}$ (i.e. the western part of USA and Mexico), and in the winter in the areas draining to the West Atlantic, and the Arctic Ocean. In these areas, the presence of reservoirs tends to increase runoff to the ocean in the winter and decrease runoff during the snow melt period, while irrigation decreases runoff in the summer in the USA and Mexico. In 1950, the largest changes from the 1700 conditions are in the area draining to the Eastern Pacific south of $49 \mathrm{~N}$. The increasing number of dams and extent of irrigated areas in the 1900's in North America are obvious when looking at the graphs for 1900, 1950, and 1992. Figure 7 also indicates that the main impact of dams in Asia occurred after 1950, see also Fig. 1.

The effects of land use changes (i.e. the difference between simulations 1 and 4 in Fig. 7) are most noticeable in the North American area draining to the Gulf of Mexico, and the Asian areas draining to the Pacific Ocean. These areas all experiences higher current than historical runoff, given no irrigation and no reservoirs. Figure $7 \mathrm{i}$ indicates that reservoir and irrigation practices decreases runoff by about the same amount as decreased forest cover increases runoff in this area, whereas irrigation water use in South East Asia (Fig. 7h) does not balance the increase in runoff caused by decreased forest cover, see also Fig. 6 .

Figure 8 shows accumulated volume of freshwater reaching the oceans, and indicates that the area in North America draining to the Gulf of Mexico, and the area in South East Asia draining to the Western Pacific Ocean, are the two areas where annual runoff volumes have been most affected by land use changes, at least in a relative sense. For the area draining to the Gulf of Mexico, the simulation results for 1992 without the reservoir and irrigation model implemented, indicates an increase in runoff of 9 percent, compared to the simulation results for 1700 . However, because of irrigation water use, the current simulated runoff with the reservoir and irrigation scheme implemented is only 3.5 percent higher than the 1700 results. In South East Asia (the area draining to the Pacific Ocean), the corresponding numbers are 12 and 11 percent.

This study illustrates that replacing forest by cropland in general decreases evapotranspiration and increases runoff, 

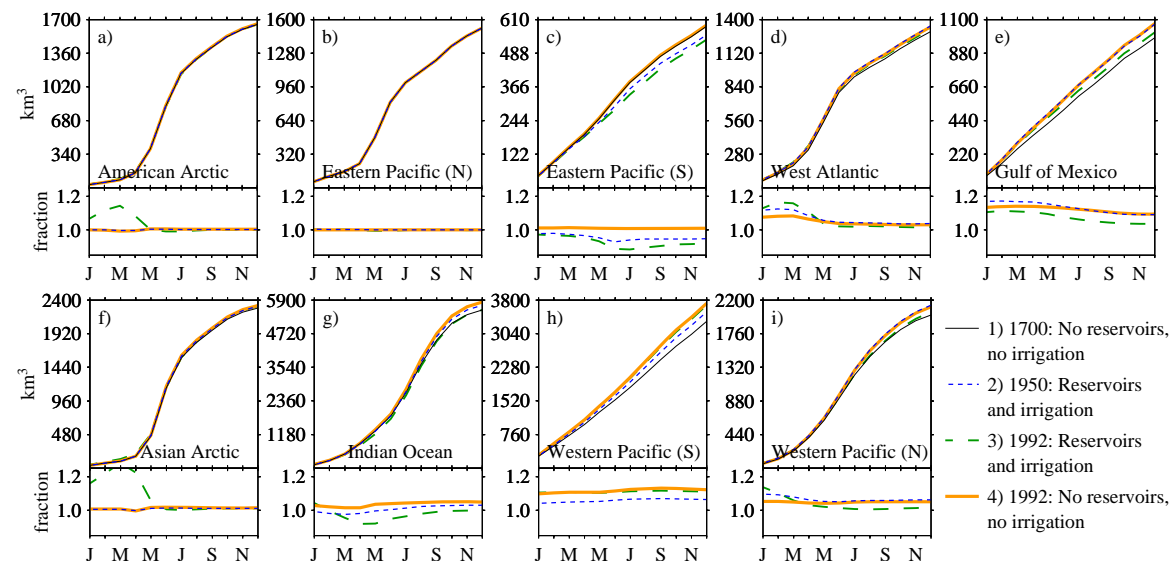

Fig. 8. Accumulated volume freshwater reaching the oceans. (a) represents rivers draining northwards to the Arctic Ocean in the North American region (including Hudson Bay), (b) and (c) represent rivers draining North America to the Pacific Ocean north and south of $49 \mathrm{~N}$, respectively. (d) represents rivers draining North America to the Atlantic Ocean, (e) represents rivers draining to the Gulf of Mexico, (f) represents rivers draining northwards to the Arctic Ocean in the Asian region, (g) represents rivers draining Asia to the Indian Ocean, and (h) and (i) represent rivers draining Asia to the Pacific Ocean north and south of the Tropic of Cancer, respectively. The lower panels show the results of simulations 2,3 and 4 divided by simulation 1 .

and that irrigation increases evapotranspiration and decreases runoff. However, dams and reservoirs have by large the most important effects on river runoff, and reservoir operations can radically change the shape of a river's seasonal hydrograph. Taken together, river management (reservoirs and irrigation) has resulted in profound changes in the dynamics of several rivers, and the results presented here demonstrate the need for integrated river basin management in order to consider the effects of human interventions in a river basin.

\subsection{Uncertainties in input data}

The results presented here are dependent on the quality of the current and historical vegetation and irrigation images, and the method chosen when constructing these images will influence the results. The quality of the irrigation map is discussed in Siebert et al. (2005b). In short, they conclude that the quality is good in North America (very good in the USA), and in Asia except Russia. In Russia, the quality of the map is characterized as poor, mainly due to lack of recent information at the sub-national level needed to verify the dataset. Siebert et al. (2005b) also compared their dataset to other global land cover datasets that include irrigated areas, and concluded that their irrigation map, which is based on sub-national irrigation statistics and geospatial information on irrigation schemes, is more reliable than those based on remote sensing information.

It should be kept in mind that the land use changes taken into account in this study only include areas converted to cropland. As pointed out by Ramankutty and Foley (1999), other forms of land use changes can have important hydrological consequences. The dataset of Goldewijk (2001) takes into account areas converted to pasture, in addition to areas converted to cropland, and was a candidate for use in this study. We decided not to do so because the version available at the time of this study included one vegetation type within each 0.5 degree grid cell (the datasets from SAGE were available at finer resolution, see Sect. 3.1). In the Goldewijk (2001) dataset more than 40 percent of global land areas are identified as cropland (11 percent) or pasture ( 23 percent), whereas 15 percent of global land areas are identified as cropland in the dataset by Ramankutty and Foley (1999). The largest hydrological consequences of this choice are likely to be found in areas converted from forest to cropland or pasture. In the Ramankutty and Foley (1999) image, forested areas have decreased by 11.5 percent on the global scale, while the corresponding number for the Goldewijk (2001) dataset is 17 percent. The accuracy and applicability of the datasets are thoroughly discussed in Ramankutty and Foley (1999) and Goldewijk (2001).

The potential vegetation does not necessarily represent the natural pre-agricultural vegetation, but instead represent vegetation that likely would exist today given no human activities or other disturbances, such as fire (Ramankutty and Foley, 1999). Ramankutty and Foley (1999) acknowledge that the quality of the cropland dataset for 1700 is poorer than the quality of the more recent cropland datasets. Also, due to lack of adequate subnational data, deficiencies exist in the cropland data for the Former Soviet Union (Ramankutty and Foley, 1999).

Areas of incorrect classifications of vegetation types and the location and amount of irrigated areas are inevitable. At the continental and annual scales, the simulated changes in runoff and evapotranspiration caused by human activities are 
relatively minor (see Fig. 5), and the results would probably be minor even if the reconstruction of cropland areas and irrigated areas were in error by, say, a factor 2 . However, at the local and seasonal scale where the apparent signal is stronger, the results and their implications will be more sensitive to the input data used.

\subsection{Uncertainties in the modeling scheme}

Simulated irrigation water use is most likely somewhat underestimated, given that groundwater withdrawals, and canals and aqueducts built for irrigation water transport, are not included in the modeling scheme, see also discussions in Haddeland et al. (2006a, b). In Haddeland et al. (2006b) it was shown that the modeling scheme presented here underestimates irrigation water use e.g. for the US High Plains, where groundwater withdrawals are known to be important.

The reservoir data set used in this study includes about 70 percent of the global storage volume in the ICOLD (2003) database. The dataset does not, for example, include any dams on the Arabian Peninsula, and, combined with the fact that groundwater withdrawals are important for irrigation on the Arabian Peninsula (FAO, 1997), this results in only small increases in evapotranspiration on the Arabian Peninsula. Other similar local discrepancies are likely to exist.

Current simulated irrigation water use is 48 and 43 percent less than current simulated irrigation water requirements for North America and Asia, respectively (Fig. 6 and Table 2). Reported irrigation water use for several states in the USA is less than simulated irrigation water requirements (Haddeland et al., 2006b). Numbers on irrigation water use for Asia are not available, but freshwater scarcity is identified in several river basins in North America and Asia (Falkenmark and Lannerstad, 2005). Hence, the difference between irrigation water requirements and irrigation water use cannot be entirely connected to model deficiencies (groundwater, canals, and dams).

For the 1950 and 1992 simulations, the same vegetation image is used for the simulation where irrigation is taken into account, and the simulation without irrigation. Wilting of plants is not taken into account in the model, which might have affected leaf area index somewhat in the simulations where irrigation is not taken into account. Both these factors would most likely have increased the difference between the two simulations performed for 1950 and 1992.

\section{Conclusions}

Simulation results indicate an increase in annual runoff between 1700 and 1992 caused by cropland expansions, without taking irrigation into account, in North America and Asia of 2.5 and 6 percent, respectively. The runoff increases are caused by conversion of forest and woodland to cropland. Simulated runoff values in North America in 1950 were even higher than the current (1992) ones, considering the effect of land use changes alone, but the agricultural expansion in the 20th century has replaced large grassland areas, resulting in slightly lowered runoff. Irrigation increases evapotranspiration and decreases runoff, and in North America irrigation water use to some extent cancels out the simulated increase in runoff caused by land use changes over the past 300 years. In the Asian region, simulated irrigation water requirements for current conditions are slightly lower than the simulated increase in runoff caused by land use changes. However, simulated irrigation water use is only about half the amount of irrigation water requirements, which indicates that simulated water use is underestimated, or that crops experience water stress.

The areas draining to the Arctic Ocean are, on average, insignificantly affected by land use changes and irrigation. However, dam construction has altered the runoff regimes somewhat in these areas, especially in March when simulated current runoff is between 20 and 40 percent higher than simulated historical runoff for the northern part of North America and Asia. On the basis of the total impact of land use changes, irrigation, and dams, the relatively largest changes in annual runoff volumes are simulated in the South East Asian area draining to the Pacific Ocean, where simulated current annual runoff volumes are 11 percent higher than the simulated historical runoff volumes. The largest changes caused by land use changes alone are also simulated in the South East Asian area, where current simulated annual runoff is 12 percent higher than historical simulated runoff. Irrigation practices decrease annual runoff volumes the most in the area draining the western part of USA and Mexico, where current simulated annual runoff volume with the irrigation and reservoir model implemented is 9 percent lower than current simulated annual runoff volume without the irrigation and reservoir model implemented. For the same area, the maximum monthly decrease in runoff is 25 percent, and is caused by reservoir operations combined with irrigation practices.

Acknowledgements. The first author acknowledges support by a University grant at the University of Oslo.

Edited by: L. A. Swatuk

\section{References}

Bowling, L. C., Lettenmaier D. P., Nijssen, B., Graham, L. P. et al.: Simulation of high latitude hydrological processes in the TorneKalix basin: PILPS Phase 2(e) 1: Experiment description and summary intercomparisons, Global Planet. Change, 38(1-2), 130, 2003.

Christensen, N. S., Wood, A. W., Voisin, N., Lettenmaier, D. P., and Palmer, R. N.: Effects of climate change on the hydrology and water resources of the Colorado River basin, Climatic Change, 62(1-3), 337-363, 2004. 
Costa, M. H., Botta, A., and Cardille, J. A.: Effects of large-scale changes in land cover on the discharge of the Tocantins River, Southeastern Amazonia, J. Hydrol., 283, 206-217, 2003.

Döll, P., and Siebert, S.: Global modeling of irrigation water requirements, Water Resour. Res. 38(4), 1037, doi:10.1029/2001WR000355, 2002.

Falkenmark, M. and Lannerstad, M.: Consumptive water use to feed humanity - curing a blind spot, Hydrol. Earth Sys. Sci., 9, 15-28, 2005.

FAO: Irrigation in the Near East region in figures, Water Reports 9, Food and Agriculture Organization of the United Nations ,1997.

FAO: Digital soil map of the world and derived soil properties. Land and Water Digital Media Series 1, CD-ROM, Food and Agriculture Organization of the United Nations, 1998.

Gibbard, S., Caldeira, K., Bala, G., Phillips, T. J., and Wickett, M.: Climate effects of global land cover changes, Geophys. Res. Lett., 32, L23705, doi:10.1029/2005GL024550, 2005.

Goldewijk, K. K.: Estimating global land use changes over the past 300 years: The HYDE Database, Global Biogeochem. Cycles, 15(2), 417-433, 2001.

Gordon, L. J., Steffen, W., Jönsson, B. F., Folke C., Falkenmark, M., and Johannessen, Å.: Human modification of global water vapor flows from the land surface, Proc. Natl. Acad. Sci. USA, 102, 7612-7617, 2005.

Haddeland, I., Lettenmaier, D. P., and Skaugen, T.: Effects of irrigation on the water and energy balances of the Colorado and Mekong river basins, J. Hydrol., 324(1-4), 210-223, 2006 a.

Haddeland, I., Skaugen, T., and Lettenmaier, D. P.: Anthropogenic impacts on continental surface water fluxes, Geophys. Res. Lett., 33, L08406, doi:10.1029/2006GL026047, 2006b.

Hanasaki, N., Kanae, S., and Oki, T.: A reservoir operation scheme for global river routing models, J. Hydrol., 327(1-2), 22-41, 2006.

Hansen, M. C., DeFries, R. S., Townshend, J. R. G., and Sohlberg, R.: Global land cover classification at $1 \mathrm{~km}$ spatial resolution using a classification tree approach, Int. J. Remote Sens., 21(67), 1331-1364, 2000.

ICOLD (International Commission on Large Dams): World Register of Dams 2003, Paris, France, 340 pp, 2003.

Kalnay, E., Kanamitsu, M., Kistler, R., Collins, W., Deaven, D., Gandin, L., Iredell, M., Saha, S., White, G., Woollen, J., Zhu, Y., Leetmaa, A., and Reynolds, B.: The NCEP/NCAR 40-year reanalysis project, Bull. Am. Meteor. Soc., 77(3), 437-472, 1996.

Liang, X., Lettenmaier, D. P., Wood, E. F., and Burges, S. J.: A simple hydrologically based model of land surface water and energy fluxes for general circulation models, J. Geophys. Res., 99(D7), 14 415-14 428, 1994.

Lobell, D. B., Bala, G., and Duffy, P. B.: Biogeophysical impacts of cropland management changes on climate, Geophys. Res. Lett., 33, L06708, doi:10.1029/2005GL025492, 2006.

Lohmann, D., Raschke, E., Nijssen, B., and Lettenmaier, D. P.: Regional scale hydrology: I. Formulation of the VIC-2L model coupled to a routing model, Hydrolog. Sci. J., 43(1), 131-141, 1998.

Matheussen, B., Kirschbaum R. L., Goodman I.A., O'Donnell G. M., and Lettenmaier D. P.: Effects of land cover change on streamflow in the interior Columbia River Basin (USA and Canada), Hydrol. Process., 14(5), 867-885, 2000.

Maurer, E. P., Wood, A. W., Adam, J.C., Lettenmaier, D. P., and Nijssen, B.: A long-term hydrologically-based data set of land surface fluxes and states for the conterminous United States, J. Climate, 15, 3237-3251, 2002.

Miller, D. A. and White, R. A.: A conterminous United States multilayer soil characteristics dataset for regional climate and hydrology modeling. Earth Interactions, 2, 1998.

Myneni, R. B., Nemani, R. R., and Running, S. W.: Estimation of global leaf area index and absorbed PAR using radiative transfer models, IEEE Trans. Geosci. Remote Sens., 35(6), 1380-1393, 1997.

Nijssen, B., Schnur, R., and Lettenmaier, D. P.: Global retrospective estimation of soil moisture using the Variable Infiltration Capacity land surface model, 1980-1993, J. Clim., 14, 1790-1808, 2001.

Nilsson, C., Reidy, C. A., Dynesius, M., and Revenga, C.: Fragmentation and Flow Regulation of the World's Large River Systems, Science, 308, 405-408, 2005.

Postel, S. L., Daily, G. C., and Ehrlich, P. R.: Human appropriation of renewable freshwater. Science, 271, 785-788, 1996.

Ramankutty, N. and Foley, J. A.: Estimating historical changes in global land cover: Croplands from 1700 to 1992, Global Biogeochem. Cycles, 13(4), 997-1027, 1999.

Sahin, V. and Hall, M. J.: The effects of afforestation and deforestation on water yields, J. Hydrol., 178, 293-309, 1996.

Siebert, S., Döll, P., Feick, S., and Hoogeveen, J.: Global map of irrigated areas version 3.0 Johann Wolfgang Goethe University, Frankfurt am Main, Germany / Food and Agriculture Organization of the United Nations, Rome, Italy, 2005a.

Siebert S., Döll, P., Hoogeveen, J., Faures J.-M., Frenken, K., and Feick, S.: Development and validation of the global map of irrigated areas, Hydrol. Earth Sys. Sci., 9, 535-547, 2005b.

Todini, E.: The ARNO rainfall-runoff model, J. Hydrol., 175(1-4), 339-382, 1996.

Twine, T. E., Kucharik, C. J., and Foley, J. A.: Effects of land cover change on the energy and water balane of the Mississippi river basin, J. Hydrometeorol., 5(4), 640-655, 2004

Vitousek, P. M., Mooney, H. A., Lubchenco, J., and Melillo, J. M.: Human Domination of Earth's Ecosystems, Science, 277, 494 499, 1997.

Vörösmarty, C. J., Sharma, K., Fekete, B., Copeland, A. H., Holden, J., Marble, J., and Lough, J. A.: The storage and aging of continental runoff in large reservoir systems of the world, Ambio, 26, 210-219, 1997.

Vörösmarty, C. J., Meybeck, M., Fekete, B., Sharma, K., Green, P., and Syvitksi, J.: Anthropogenic sediment retention: Major global impact from registered river impoundments, Global Planet. Change, 39, 169-190, 2003.

Vörösmarty, C. J. and Sahagian, D.: Anthropogenic disturbance of the terrestrial water cycle, Bioscience, 50(9), 735-765, 2000.

Vrugt, J. A., Gupta, H. V., Bouten, W., and Sorooshian, S.: A Shuffled Complex Evolution Metropolis algorithm for optimization and uncertainty assessment of hydrologic model parameters, Water Resour. Res., 39(8), 1201, doi:10.1029/2002WR001642, 2003.

Zhao, R. J., Zhang, Y. L., Fang, L. R., Liu, X. R., and Zhang, Q. S.: The Xinanjiang model, in: Hydrological Forecasting: Proceedings of the Symposium on the Application of Recent Developments in Hydrological Forecasting to the Operation of Water Resource Systems, held at Oxford, IAHS no. 129, 351-356, 1980. 